\title{
Developing Objective Criteria for Promotion
}

\author{
C. Heather Scalf \\ University of Texas at Arlington, USA
}

\begin{abstract}
While the Association of College and Research Libraries provides guidelines for appointment, promotion, and tenure of librarians with faculty status, ${ }^{1}$ few academic libraries have created an objective set of categories and activities that is designed to reflect the broad range of professional work that can be produced by librarians and archivists in today's academic libraries. This paper will give a brief discussion and a description of the policy and the rubric created by the University of Texas Arlington (UTA) Libraries Associates of the Faculty Promotion Policy Task Force. The policy and the rubric were designed to provide an objective and progressive tool that could be used for candidates to self-assess their progress over the course of their career, and for the promotion committee to evaluate the evidence submitted in the candidate's dossier when an application for promotion was received. They address performance and evidence in three categories: librarianship, scholarly materials and activities, and service.
\end{abstract}

The rubric is designed to not only expand upon the evidence definitions created by the policy, but also to provide examples and criteria that will indicate the level of success evidenced by the supporting documentation. It provides a scoring strategy for each of the three categories based upon quantity, quality, or complexity of the activity that evaluates not only traditional types of scholarship and service, but also emerging scholarship and service as well.

\section{Introduction}

The UTA Libraries has had a promotion policy for nearly 20 years, which was intended to provide a mechanism for advancement for librarians and archivists outside of the management structure within the libraries. In 2013, a task force was charged by the dean of libraries to begin the process of drafting a new policy and an associated evaluation rubric. A comprehensive review of the literature related to tenure and promotion of academic librarians showed that the conversation in this area has largely revolved around the concept and definition of faculty status for academic librarians. While librarians and archivists within the University of Texas system do not have faculty status, and in fact have a unique status as associates of the faculty, the committee felt that an environmental scan of what the tenure and promotion process looked like, regardless of the possibility of tenure at our institution, would benefit its work. A national survey conducted by Betsy Park and Robert Riggs in $1989^{2}$ collected and compared the standards used to evaluate academic librarians for promotion, among other things. Their College \& Research Libraries article, "Status of the Profession: A 1989 National Survey of Tenure and Promotion Policies for Academic Librarians," urged the development of guidelines in academic libraries to make the promotion process more transparent.

Subsequent articles by other practitioners broadly concurred with this recommendation, whether they were based upon internal reviews of policy, system level policy reviews, or national survey results.

Armed with this perspective and a charge from the dean of libraries to develop a more transparent promotion policy, the task force was created to do this work. This task force was initially composed of the original career status committee with two additional members. Some members of the group were managers and others were not. The group set about revising the libraries' existing policy, which had been in effect since 1995. The legacy policy addressed titles, equal opportunity employment and affirmative action, eligibility requirements, application to new hires, roles and responsibilities, and composition of the career status committee. Although some minor revisions had taken place in the previous five years, no substantive changes had been made.

\section{Methodology}

The first order of business was defining the desired outcomes of the initial charge. These were: creation of a coaching element specifically for supervisors, clear specifications for the use of recommendation guidelines, 
inclusion of a mentoring element for new associates of the faculty, an opt-in or opt-out provision for all librarians and archivists, and criteria that were clear and objective and provided a clear pathway for development and promotion, as well as required documentation from both the supervisor and the review committee which could be provided to the candidate. Specifically, the policy should express a balance of both internal and external service and scholarship and reflect new models of intellectual engagement and contribution along with more traditional methods.

After clarifying the charge, the task force completed a literature review and an environmental scan to determine the current best practices. This was followed by a structured interview of 13 questions conducted with peers from libraries at four other institutions: one peer, two aspirational peers, and one small private college. The interviews resulted in identification of several themes, the most relevant of which were:

1. Just as had been discovered in the literature review, faculty status varied among the institutions that were interviewed.

2. All four institutions had progressive ranks or levels, three were similar to UTA, having assistant librarian, associate librarian, and librarian and one having librarians I through IV.

3. All institutions had transparent processes, which is to say that candidates were provided written feedback indicating the committee's decision.

4. There was no opt-out process for the first level of promotion at three of the four libraries, participation was required, and, in fact, if promotion was not received at those institutions, employment was terminated.

After interviewing a senior university administrator about the dean's desire to have a true tenure policy and realizing that this was not possible, it was decided that the new policy would mirror as closely as possible the non-tenure-stream faculty guidelines at UTA for promotion.

\section{The Process}

During the environmental scan, the framework set forth in the policy from the private college impressed the task force members sufficiently that permission was sought and obtained to use it as a foundational document. It would be the foundation for the document that would be created over the next three years, with the task force meeting weekly for three hours to work on it as a group. The task force paid great attention to the necessary balance between the dean's charge and the needs of the associates of the faculty. At several points during the process, sections of the working document were shared with all associates of the faculty for their feedback and input. While no promises were made as to inclusions or changes, care was taken to ensure that the task force was keeping all perspectives in balance.

Because participation could not be mandated, the policy describes two tracks for librarians and archivists. Track 1 is for those on the promotion pathway and Track 2 is for those who are choosing not to participate. Associates of the faculty on Track 1, the promotion track, receive additional incentives of a guaranteed base of financial support for professional development and travel, along with additional support for participation, such as conference presentations or committee work, as well as salary advancement as part of the promotion process. Those on Track 2 have no guaranteed support for professional activities and no salary increase based upon promotion, although they are still eligible for the university's merit increases, as all employees are.

Ultimately, the new policy included three broad categories of activity that were required of all librarians and archivists to be considered for promotion: librarianship, scholarship, and service. In order to increase objectivity and transparency in the process, a rubric was created so that candidates could evaluate their own dossier using the same criteria that the promotion recommendation committee would use. While the broad categories were clearly described in the policy itself, the rubric provides specific examples in each category, 
with points associated with each type and/or frequency of activity. General descriptions of the three categories are:

- Librarianship-scoring reflects performance in the primary role. It is evaluated and scored using two metrics: average score on a minimum of two performance evaluations at UTA and the supervisor's recommendation for promotion, which is a pass/fail requirement.

- Scholarship-this was designed to be comprehensive but not explicit. This section is subdivided into formal scholarly publications, informal scholarly publications, and scholarly materials or activities. The challenge for the task force was to write descriptions that were general enough to allow for future activity that might not yet be imagined, but still specific enough to be useful in helping candidates evaluate their own performance. The supporting rubric provides much greater specificity with regard to scholarly output and activity. The broadness of the policy definition was intentional, as any future changes to the policy would require a successful vote by the associates of the faculty.

- Service-this includes service to the profession, at any level, from local to international, as well as teaching outside of core job requirements, mentoring, and supervision.

Each section is weighted as a percentage of the total, with a minimum number of points that must be achieved in each one in order for a candidate to be promoted. These section minimums must also be achieved in all sections, or the candidate is not promoted. The weighted values are different depending upon which rank a candidate aspires to. For those applying from assistant to associate librarian or archivist, job performance is weighted more heavily, while advancement to the senior rank requires more scholarly activity and service to the profession. And there is an overall requirement that there must be some activity in each category within the five years prior to application in order to be successful.

The policy itself defines all of the elements that must be included as part of a complete dossier, and candidates are told what kind of supporting documentation defines evidence of activity. The order of the completed dossier is provided, and the associated evidence for each activity is required to be included. The completed submission should be one continuous PDF document, submitted digitally for review by the promotion committee.

\section{Rubric Creation}

Merriam Webster defines a rubric as "a guide listing specific criteria for grading or scoring academic papers, projects, or tests." According to James Popham, rubrics have three essential features: evaluative criteria, quality definitions, and a scoring strategy. ${ }^{3}$ In her 2009 guide for librarians about the information literacy instruction assessment cycle, Megan Oakleaf posited that when it comes to learning outcomes, rubrics offer a specific and systematic way to examine them and a method to examine tangible evidence of that learning. ${ }^{4}$ The task force felt that a progressive description and evaluation of activities could best be expressed in the form of a rubric, one that would attempt to equate different activities based upon intellectual effort. While there is some subjectivity in the evaluation of intellectual effort, this was agreed to be the best starting point for the creation of an objective set of standards that would inform and guide all librarians and archivists. Beginning with the general list of activities from the policy itself, the task force then crowdsourced this list to add more details that could be used to create a comprehensive rubric. This was done both locally with our peer group and virtually, through several email lists that various task force members participated in.

As previously mentioned, the policy reflects activity in three broad categories. The rubric itself is an Excel workbook composed of seven worksheets. The first worksheet is an introduction, which describes how each worksheet should be used and how scoring and weighting of results is done. The second worksheet evaluates the completion of the dossier provided, as well as librarianship. As can be seen in Figure 1, all items from the required list must be submitted or the candidate does not progress. 
Figure 1. Promotion Policy Rubric, Librarianship

\section{Scoring Rubric}

\begin{tabular}{|c|c|c|c|c|}
\hline \multicolumn{5}{|c|}{ Items I-VIII from the Documentation for Candidates for Promotion submitted? YES } \\
\hline \multicolumn{5}{|c|}{ Section 1: Librarianship or Archival Work ( $60 \%$ for associate and $45 \%$ for senior) } \\
\hline Category & $\begin{array}{l}\text { Superlative } \\
\text { Contributions } \\
\text { (3 points) }\end{array}$ & $\begin{array}{l}\text { Adequate Contributions } \\
\text { ( } 2 \text { points })\end{array}$ & $\begin{array}{l}\text { Minimal Contributions } \\
\text { (1 point) }\end{array}$ & $\begin{array}{c}\text { No Substantive } \\
\text { Contributions ( } 0 \\
\text { points) }\end{array}$ \\
\hline $\begin{array}{l}\text { Average scores from performance evaluation } \\
\text { documents }\end{array}$ & $\begin{array}{l}\text { Expert } \\
\text { (Outstanding) } \\
\end{array}$ & Proficient (Solid performer) & $\begin{array}{l}\text { Developing (Needs } \\
\text { improvement) }\end{array}$ & Unsatisfactory \\
\hline \multirow[t]{2}{*}{\begin{tabular}{|l|l|} 
Supervisor supports promotion & \\
\end{tabular}} & $\mathrm{N} / \mathrm{A}$ & Yes & $\mathrm{N} / \mathrm{A}$ & No \\
\hline & 0 & 0 & 0 & \\
\hline Candidate's total for Section 1 & & 0 & & \\
\hline Total possible for Section 1 & & 5 & & \\
\hline
\end{tabular}

The third, fourth and fifth worksheets are used to evaluate scholarly publications and activities, with one worksheet for each of the three subgroups mentioned above. Section $2 \mathrm{~A}$ reflects evaluation of more traditional publications, such as books, book chapters, and articles. The following two figures illustrate how point assignments vary within the same rubric in order to recognize what is regarded to be higher levels of intellectual effort required for a given activity.

Figure 2. Promotion Policy Rubric, 2A, top.

Section 2: Scholarly Materials or Activities (20\% for associate and $\mathbf{3 0} \%$ for senior)

Part A.1: Formal Scholarly Publications*

\begin{tabular}{|l|l|l|l|}
\hline \multicolumn{1}{|c|}{9 points } & \multicolumn{1}{|c|}{6 points } & \multicolumn{1}{c|}{3 points } \\
\hline $\begin{array}{l}\text { Solo-authored book published } \\
\text { by a scholarly press }\end{array}$ & $\begin{array}{l}\text { Coauthored or solo-edited book published by } \\
\text { a scholarly press }\end{array}$ & $\begin{array}{l}\text { Coedited book published by a scholarly } \\
\text { press }\end{array}$ & No book \\
\hline $\begin{array}{l}\text { 3 OR MORE Solo-authored } \\
\text { peer-reviewed journal articles }\end{array}$ & $\begin{array}{l}2 \text { Solo-authored peer-reviewed journal } \\
\text { articles }\end{array}$ & $\begin{array}{l}1 \text { Solo-authored peer-reviewed journal } \\
\text { article }\end{array}$ & No articles \\
\hline $\begin{array}{l}3 \text { OR MORE Solo-authored } \\
\text { chapter contributions to an } \\
\text { edited book }\end{array}$ & $\begin{array}{l}2 \text { Solo-authored chapter contributions to an } \\
\text { edited book }\end{array}$ & $\begin{array}{l}1 \text { Solo-authored chapter contribution to } \\
\text { an edited book }\end{array}$ & No chapters \\
\hline & & $n$ & $n$
\end{tabular}


Figure 3. Promotion Policy Rubric, Section 2A, bottom.

\begin{tabular}{|c|c|c|c|}
\hline \multicolumn{4}{|c|}{ Part A.2: Formal Scholarly Publications* } \\
\hline 6 points & 4 points & 2 points & 0 points \\
\hline $\begin{array}{l}\text { OR MORE Coauthored peer } \\
\text { reviewed journal articles }\end{array}$ & 2 Coauthored peer-reviewed journal articles & $\begin{array}{l}1 \text { Coauthored peer-reviewed journal } \\
\text { article }\end{array}$ & No articles \\
\hline $\begin{array}{l}3 \text { OR MORE Coauthored } \\
\text { contributions to an edited book }\end{array}$ & 2 Coauthored contributions to an edited book & $\begin{array}{l}1 \text { Coauthored contribution to an edited } \\
\text { book }\end{array}$ & No chapters \\
\hline 0 & 0 & 0 & \\
\hline 3 points & 2 points & 1 point & 0 points \\
\hline $\begin{array}{l}3 \text { or more articles in a journal } \\
\text { or trade publication that are not } \\
\text { peer-reviewed }\end{array}$ & $\begin{array}{l}2 \text { articles in a journal or trade publication that } \\
\text { are not peer-reviewed }\end{array}$ & $\begin{array}{l}1 \text { article in a journal or trade publication } \\
\text { that are not peer-reviewed }\end{array}$ & No articles \\
\hline 6 or more book reviews & 5 book reviews & 1-4 book reviews & No book reviews \\
\hline
\end{tabular}

Worksheet Section 2B is used to evaluate less formal publications, such as project related working papers, technical guidelines produced at any level and includes participation in a grant related project as well as participation in social media outlets that are "in-depth, substantive, currently relevant, and focused on the profession itself." As seen in Figure 4 below, this also includes activities such as software or app creation or derivative works of that kind.

Figure 4. Promotion Policy Rubric, Section 2B, bottom.

\begin{tabular}{|c|c|c|c|}
\hline $\begin{array}{l}\text { Creation and continued } \\
\text { administration of } 2 \text { or more } \\
\text { nationally known social media } \\
\text { outlets that are in-depth, } \\
\text { substantive, currently relevant, and } \\
\text { focused on the profession itself (i.e., } \\
\text { archives and libraries) or on issues } \\
\text { closely related to the profession } \\
\text { (e.g., a blog AND a Twitter } \\
\text { account that have } 2000 \text { or more } \\
\text { followers each) }\end{array}$ & $\begin{array}{l}\text { Creation and continued administration of } 1 \\
\text { nationally known social media outlet that is in } \\
\text { depth, substantive, currently relevant, and } \\
\text { focused on the profession itself (i.e., archives } \\
\text { and libraries) or on issues closely related to } \\
\text { the profession (e.g., a blog OR a Twitter } \\
\text { account that has } 2000 \text { or more followers) } \\
\text { OR } 30 \text { or more postings to others' blogs or } \\
\text { a Listserv that are in-depth, substantive, and } \\
\text { focused on the profession }\end{array}$ & $\begin{array}{l}\text { Creation and continued administration } \\
\text { of } 1 \text { or more social media outlets that } \\
\text { are in-depth, substantive, currently } \\
\text { relevant, and focused on the } \\
\text { profession itself (i.e., archives and } \\
\text { libraries) or on issues closely related to } \\
\text { the profession (e.g., a blog OR a } \\
\text { Twitter account) OR } 20-29 \text { postings } \\
\text { to others' blogs or a Listserv that are } \\
\text { in-depth, substantive, and focused on } \\
\text { the profession }\end{array}$ & $\begin{array}{l}\text { No creation a1 } \\
\text { continued } \\
\text { administration } \\
\text { social media o } \\
\text { than } 19 \text { contril } \\
\text { to Listservs }\end{array}$ \\
\hline $\begin{array}{l}3 \text { or more articles in or shorter } \\
\text { contributions to international or } \\
\text { national news outlets, magazines, or } \\
\text { other popular press outlets }\end{array}$ & $\begin{array}{l}3 \text { or more articles in or shorter contributions } \\
\text { to city or state news outlets, magazines, or } \\
\text { other popular press outlets }\end{array}$ & $\begin{array}{l}3 \text { or more articles in or shorter } \\
\text { contributions to university or library } \\
\text { news outlets, magazines, or other } \\
\text { popular press outlets }\end{array}$ & $\begin{array}{l}2 \text { or fewer arti } \\
\text { or shorter } \\
\text { contributions } t \\
\text { popular press }\end{array}$ \\
\hline 0 & 0 & 0 & \\
\hline 9 points & 6 points & 3 points & 0 point \\
\hline $\begin{array}{l}\text { Original or derivative creation of } 4 \\
\text { or more mobile apps or other } \\
\text { software relevant to librarianship or } \\
\text { archival work }\end{array}$ & $\begin{array}{l}\text { Original or derivative creation of 2-3 mobile } \\
\text { apps or other software relevant to } \\
\text { librarianship or archival work }\end{array}$ & $\begin{array}{l}\text { Original or derivative creation of } 1 \\
\text { mobile apps or other software relevant } \\
\text { to librarianship or archival work }\end{array}$ & $\begin{array}{l}\text { No creation o: } \\
\text { apps or other } \\
\text { software }\end{array}$ \\
\hline
\end{tabular}

The worksheet for Section $2 \mathrm{C}$ provides evaluation for scholarly activities, including things such as conference and workshop presentations, work in service of a conference or journal, and creation of digital 
learning objects and datasets. Figure 5 provides some of the clearest examples of how the task force defined point differentials between activities. In this case, presenting a national or international preconference is valued more highly than a state or local level preconference, although it is possible for a candidate to score points in both. This example also clearly illustrates a decision that there were some activities that would be more limited in the points that could be accrued, in order to encourage associates of the faculty to have greater breadth in their scholarly work. Points earned for conference presentations will top out at " 3 or more.” There are similar upper limits for some formal scholarship as well. While this may seem counterintuitive when considering that the total points earned are what result in promotion or not, the task force felt very strongly that librarians and archivists should have a broad variety of professional contributions and activities.

Figure 5. Promotion Policy Rubric, Section 2C, top.

\begin{tabular}{|c|c|c|c|}
\hline \multicolumn{4}{|c|}{ Part C: Scholarly Activities } \\
\hline 3 points & 2 points & 1 point & 0 points \\
\hline $\begin{array}{l}\text { Service as an editor of a peer-reviewed } \\
\text { journal }\end{array}$ & $\begin{array}{l}\text { Service as an invited editor of a special issue of a } \\
\text { peer-reviewed journal OR service as a reviewer of } \\
\text { a peer-reviewed journal }\end{array}$ & $\begin{array}{l}\text { Service as a reviewer of proposals } \\
\text { for a scholarly conference }\end{array}$ & $\begin{array}{l}\text { No service as an } \\
\text { or reviewer for a } j \\
\text { or conference }\end{array}$ \\
\hline $\begin{array}{l}\text { Presenter at a preconference workshop at } \\
\text { a national or international conference }\end{array}$ & $\begin{array}{l}\text { Presenter at a preconference workshop at a state } \\
\text { or multistate regional conference }\end{array}$ & $\begin{array}{l}\text { Presenter at a preconference } \\
\text { workshop at a regional (e.g., north } \\
\text { TX) or local conference }\end{array}$ & $\begin{array}{l}\text { No preconference } \\
\text { presentation }\end{array}$ \\
\hline $\begin{array}{l}\text { Invited to teach at } 1 \text { or more national-level } \\
\text { workshops (e.g., ACRL Immersion) }\end{array}$ & $\begin{array}{l}\text { Invited to teach at } 1 \text { or more state-level } \\
\text { workshops }\end{array}$ & $\begin{array}{l}\text { Invited to teach at } 1 \text { or more local- } \\
\text { level workshops }\end{array}$ & 0 teaching invitatic \\
\hline $\begin{array}{l}3 \text { or more peer-reviewed conference } \\
\text { presentations* }\end{array}$ & 2 peer-reviewed conference presentations* & $\begin{array}{l}1 \text { peer-reviewed conference } \\
\text { presentations* }\end{array}$ & $\begin{array}{l}\text { No conference } \\
\text { presentations }\end{array}$ \\
\hline
\end{tabular}

Similarly, the service worksheet evaluates contributions at many levels, from participation in library committees and campus events to participation in national organizations, as well as service as a formal mentor to a library school student or practicum participant, and any awards or honors that the candidate may have received. 
Figure 6. Promotion Policy Rubric, Section 2A, bottom.

\begin{tabular}{|c|c|c|c|}
\hline N/A & $\begin{array}{l}10 \text { or more opinion pieces in a journal or trade } \\
\text { publication }\end{array}$ & $\begin{array}{l}1-9 \text { opinion pieces in a journal or trade } \\
\text { publication }\end{array}$ & N/A \\
\hline & $\mathrm{x}$ & & \\
\hline $\begin{array}{l}3 \text { or more professionally } \\
\text { published bibliographies or } \\
\text { other substantial, special-topic } \\
\text { user guides (regular disciplinary } \\
\text { subject guides are considered } \\
\text { part of librarianship) }\end{array}$ & $\begin{array}{l}2 \text { professionally published bibliographies or } \\
\text { other substantial, special-topic user guides } \\
\text { (regular disciplinary subject guides are } \\
\text { considered part of librarianship) }\end{array}$ & $\begin{array}{l}1 \text { professionally published bibliography } \\
\text { or other substantial, special-topic user } \\
\text { guides (regular disciplinary subject } \\
\text { guides are considered part of } \\
\text { librarianship) }\end{array}$ & $\begin{array}{l}\text { No professionally published } \\
\text { bibliographies or other } \\
\text { substantial, special-topic user } \\
\text { guides (regular disciplinary } \\
\text { subject guides are considered } \\
\text { part of librarianship) }\end{array}$ \\
\hline$X$ & & & \\
\hline 3 & 2 & 0 & \\
\hline 3 & 2 & 0 & \\
\hline $\begin{array}{l}\text { Candidate's subtotal for } \\
\text { Section 2, Part A }\end{array}$ & \multicolumn{3}{|c|}{5} \\
\hline $\begin{array}{l}\text { Subtotal possible for Section 2, } \\
\text { Part A }\end{array}$ & \multicolumn{3}{|c|}{60} \\
\hline
\end{tabular}

*Invited authorship of any of the above publications will lend weight to the publication and help candidates whose score may

As shown by Figure 6, each worksheet has a summary of points achieved for that particular subcategory or category. The final worksheet (see Figure 7) is a point summary page for the entire workbook-the combined totals of the formulas from all the previous worksheets-with weighted values compared to the required weighted minimums for each rank. The candidate must meet or exceed the minimum weighted score in each of the three categories, or they will not be recommended for promotion.

Figure 7. Promotion Policy Rubric, Summary Section.

\begin{tabular}{|c|c|c|c|c|c|c|}
\hline & & C & D & & & $E$ \\
\hline & $\begin{array}{l}\text { Weighted } \\
\text { Value (\%) }\end{array}$ & $\begin{array}{l}\text { Points } \\
\text { Earned }\end{array}$ & $\begin{array}{l}\text { Total } \\
\text { expected } \\
\text { points }\end{array}$ & $\begin{array}{l}\text { Results of } \\
C / D\end{array}$ & $\begin{array}{l}\text { Candidate's } \\
\text { Score (Ex } \\
\text { Weighted } \\
\text { Value) }\end{array}$ & $\begin{array}{l}\text { Minimum weighted } \\
\text { score necessary }\end{array}$ \\
\hline Section 1: Librarianship & 60 & 0 & 5 & $0 \%$ & 0 & 48 \\
\hline Section 2: Scholarship & 20 & 5 & 23 & $22 \%$ & 4 & 17 \\
\hline Section 3: Service & 20 & 0 & 13 & $0 \%$ & 0 & 15 \\
\hline
\end{tabular}

\begin{tabular}{|l|l|l|l|l|l|l|l|}
\hline & & C & D & & E \\
\hline \multicolumn{2}{|l|}{ Senior Librarian } \\
\hline
\end{tabular}


Both the policy and the rubric are available to candidates in the Research Commons, the UTA Libraries' institutional repository. ${ }^{5}$ All associates of the faculty are encouraged to use the rubric to score themselves prior to submitting their name for promotion consideration in each year's cycle, whether that is during the two-year review for assistant librarians and archivists or prior to their dossier submission. Additionally, supervisors are required to use the rubric to evaluate their direct reports during the annual performance review process so that they may guide their professional development.

\section{Norming the Rubric}

When the rubric was completed, the task force went through a process to validate the assignment of points and overall scoring. After requesting and receiving permission from a dozen past candidates to use their archived promotion dossiers, whether for promotion to associate or senior librarian or archivist, the group scored these dossiers using the rubric to determine whether the resulting scores were consistent with past results under a less objective system. In addition to giving the group experience in the use and usefulness of the rubric, the evaluation also showed that the overall points required in the service category should be slightly increased. This activity was also the first experience of norming the rubric on a specific subset of dossiers, and the group learned a lot in the process. Claire Holmes' and Megan Oakleaf's article, "The Official (and Unofficial) Rules for Norming Rubrics Successfully," was very useful to the task force who developed the rubric, as well as the subsequent promotion policy committees who evaluated the dossiers in the cycles following approval of the policy. ${ }^{6}$ A good understanding of the "official" and "unofficial" rules helped to decrease tension when there was disagreement about scoring. Even though every attempt had been made to make the policy and the rubric as objective as possible and to create a committee with as broad a perspective as possible, there are still some activities where shared definitions are critical. One example, which indicated a need for an addition to the rubric, is the definition of a digital learning object (DLO), as described in Section 2C. Without a clear understanding of the UTA Libraries' definition of a DLO, which is found in a specific local document, it is an easy item to misunderstand.

\section{Conclusion}

Thus far, the rubric has been applied to three different groups of promotion candidates, with minor changes recommended from each cycle. It has been noted that supervisors, candidates, and committee members alike will benefit from a thorough reading and understanding of the documents. While some ambiguity within both documents was intentional in order to allow for activity that might not have been imagined by the committee during the creation of the document, a lack of understanding of the basic categories has motivated the promotion committee to offer both training and one-on-one mentoring through the process to any candidate who requests assistance. The current committee expects this need to continue to exist, and is exploring ways to mitigate some of the difficulty that candidates might experience in completing their dossier. There has been an exploration of the development of a web form for dossier creation, as well as the creation of a more durable form of the rubric for use by any associate of the faculty. Feedback from candidates has been generally positive, although preparation of the dossiers is still a very detailed and time consuming process. For those candidates who were not successful, there has been much greater clarity about what they can do to increase the number of points earned for a future application.

Norming the rubric each time that the promotion committee meets to evaluate dossiers is critical to a smooth process, and the committee has plans to create an exemplar dossier to do just that prior to evaluating actual candidate dossiers. The items chosen for this will be from a variety of different archived dossiers and the exemplar dossier will also be used to show candidates what their dossier should look like, in terms of CV and presentation of evidence. The policy and the rubric have practical implications in any libraries where librarians and/or archivists do not have faculty status within their university system, and where an objective and inclusive advancement process is desired. They are not only valuable to UTA but could also be adapted for use in any other academic library, as well as in other types of libraries.

-Copyright 2019 C. Heather Scalf 


\section{Notes}

1. Association of College and Research Libraries, "A Guideline for the Appointment, Promotion and Tenure of Academic Librarians," last modified June 2010, http://www.ala.org/acrl/standards/promotiontenure.

2. Betsy Park and Robert Riggs, "Status of the Profession: A 1989 National Survey of Tenure and Promotion Policies for Academic Librarians," College \& Research Libraries 52, no. 3 (1991): 275-289.

3. W. J. Popham, "What's wrong-and what's right-with rubrics," Educational Leadership 55, no. 2 (1997): $72-75$.

4. Megan Oakleaf, "The information literacy instruction assessment cycle: A guide for increasing student learning and improving librarian instructional skills," Journal of Documentation 65, no. 4 (2009): 539560, https://doi.org/10.1108/00220410910970249.

5. Associates of the Faculty Promotion Policy Task Force, Criteria for Promotion of Associates of the Faculty at University of Texas at Arlington Libraries, Arlington, TX: The University of Texas at Arlington Libraries, 2016, https://uta-ir.tdl.org/uta-ir/handle/10106/26302 and Associates of the Faculty Promotion Policy Task Force, Promotion Policy Rubric, Arlington, TX: The University of Texas at Arlington Libraries, 2016, https://uta-ir.tdl.org/uta-ir/handle/10106/26303.

6. Claire Holmes and Megan Oakleaf, "The Official (and Unofficial) Rules for Norming Rubrics Successfully," Journal of Academic Librarianship 39, no. 6 (2013). 